\title{
Effect of phytoplasma infection on the activity of peroxidase, $\beta-1,3$ glucanase and chitinase in corn plants
}

\author{
Ana Carolina Bruno Junqueira, Ivan Paulo Bedendo, Sérgio Florentino Pascholati
}

Departamento de Entomologia e Nematologia - ESALQ/USP, Caixa Postal 09, 13418-900 Piracicaba,SP.

Author for correspondence: I.P.Bedendo : (ipbedend@esalq.usp.br)

Data de chegada: 06/11/2010. Aceito para publicação em: 06/11/2011.

\section{ABSTRACT}

Junqueira, A.C.B.; Bedendo, I.P.; Pascholati, S.F. Effect of phytoplasma infection on activity of peroxidase, $\beta$-1,3 glucanase and chitinase in corn plants. Summa Phytopathologica, v.37, n.4, p.194-198, 2011.

In the present work we studied the effect of inoculating corn plants with the maize bushy stunt phytoplasma on the activity of the enzymes peroxidase, $\beta-1,3$ glucanase and chitinase. The experiments were carried out inside a greenhouse. Plants of a resistant and a susceptible corn hybrid were inoculated by using infective Dalbulus maidis leafhoppers 10 days after sowing. When symptoms started to appear, leaf samples were collected at different periods to quantify enzyme activity. The results showed an increase in the activity of the three enzymes in inoculated plants of both hybrids. In general, the values observed for the level of the different enzymes were higher in the susceptible hybrid when compared to the resistant one. Thus, the increases in peroxidase, $\beta-1,3$ glucanase and chitinase levels in inoculated plants are evidence of changes in the host metabolism caused by the phytoplasma. On the other hand, since the increases could not be correlated with plant resistance further studies are needed to explain such changes.

Keywords: maize stunt, pr-protein, Mollicutes, yellows.

\section{RESUMO}

Junqueira, A.C.B.; Bedendo, I.P.; Pascholati, S.F. Efeito da infecção de fitoplasma sobre a atividade de peroxidase, $\beta-1,3$ glucanase e quitinase em plantas de milho. Summa Phytopathologica, v.37, n.4, p.194-198, 2011.

No presente trabalho foi estudado o efeito da inoculação de plantas de milho com o fitoplasma, agente do enfezamento vermelho, sobre a atividade das enzimas peroxidase, $\beta-1,3$ glucanase, quitinase. Os experimentos foram conduzidos em casa de vegetação. Plantas de um híbrido de milho resistente e de um suscetível foram inoculadas através de cigarrinhas infectivas de Dalbulus maidis, 10 dias após a semeadura. Quando os sintomas começaram a aparecer, amostras de folhas foram coletadas em diferentes períodos de tempo para quantificar a atividade das enzimas. Os resultados mostraram um aumento na atividade das três enzimas em plantas inoculadas de ambos os híbridos. De maneira geral, os valores observados para o teor das diferentes enzimas foram mais elevados no híbrido suscetível quando comparado com ao resistente. Assim, os aumentos nos níveis de peroxidade, $\beta-1,3$ glucanase, e quitinase em plantas inoculadas se constituíram em evidência de alterações no metabolismo do hospedeiro causadas pelo fitoplasma. Por outro lado, uma vez que os aumentos não puderam ser correlacionados com a resistência de planta, há necessidade de novos estudos para poder interpretar estas alterações.

Palavras-chave adicionais: enfezamento do milho, pr-proteína, Mollicutes, amarelos

Phytoplasmas are associated with important diseases in several hundreds of plant species (19). Although well known as pathogens, little information is available concerning biochemical and physiological changes that occur in infected plants. Some reports have shown that the association between plants and phytoplasmas can result in changes in compounds present in plant tissue, but basically few ones are found related to the activities of peroxidases, $\beta-1,3$ glucanases and chitinases in these interactions. In corn hybrids infected with maize bushy stunt phytoplasma, changes were observed in protein, reducing sugar, phenolic compound and chlorophyll content (12). Corn plants inoculated with phytoplasma and spiroplasma agents of corn stunt showed lower protein content than non-inoculated plants (24). In plants of tobacco and Catharanthus roseus infected with phytoplasmas accumulation of carbohydrates in the leaves and lower levels in the roots of the same plants were observed (15).

Maize bushy stunt has caused significant damage to corn crops in Brazil, reaching high levels of incidence and losses $(18 ; 25)$. Thus, a comparative analysis revealed a yield reduction of up to $30 \%$ in fields without treatment insecticide for control of the vector (18). In some fields naturally infected, incidences of almost $100 \%$ were observed, resulting in total losses for the crop (25). Typical symptoms are foliar reddening, shortening internodes, ear proliferation and stunting of plants (4). Currently, phytoplasmas are not classified using binomial name system; thus, the maize bushy phytoplasma is identified as a member of group 16SrI, subgroup B $(14 ; 4)$.

One common biochemical event following infection of plants by a pathogen is the activation of pathogenesis-related (PR) genes (7; 15; 6). Currently, PR-proteins are grouped into 17 families (9), and among 
these purified proteins are the enzymes peroxidases, b-1,3 glucanases and chitinases. Thus, in order to obtain information on biochemical aspects regarding the pathosystem maize-phytoplasma, the aim of this study was to evaluate the activity of the enzymes peroxidase, b1,3 glucanase and chitinase in infected corn plants.

\section{MATERIALS AND METHODS}

A susceptible (XLX 520) and a resistant corn hybrid (FT 9006), selected in a previous experiment, were used in this study. Severe symptoms were exhibited by the susceptible hybrid, characterized by intense foliar reddening, small internodes, ear proliferation, stunting of plants and reduced grain production. Mild symptoms were present in the resistant hybrid plants and the production was higher when compared to the susceptible hybrid.

The experiments were carried out in a greenhouse. Pre-germinated seeds were sown inside plastic pots $(250 \mathrm{ml})$ with substrate composed of a mixture of soil, organic matter and sand (3:1:1 v/v/v). Ten days after sowing, plants were inoculated by using seven infective leafhoppers (Dalbulus maidis) confined per each plant and 4 days later the insects and eggs were eliminated. Twenty days after inoculation, each plant was transferred to 51 plastic bags containing the same substrate previously described. Controls were represented by insect-free plants.

Enzyme analyses were conducted from samples represented by $0.3 \mathrm{~g}$ fresh tissue each. Disks ( $1.5 \mathrm{~cm}$ in diameter) obtained from leaves of the same physiological age and situated at half of the plant height were collected one day before and 40,50, 70 and 80 days after inoculation. The experiment was in $2 \times 2 \times 5$ factorial represented by two corn hybrids (resistant and susceptible), two treatments (inoculated and non-inoculated plants) and five sampling times (1 day before, 40, 50, 70 and 80 days after inoculation). Triplicate samples for enzyme determinations were taken at each sampling time and each of the above experiments was repeated at least two times. The data were statistically analyzed by using the ESTAT program (UNESP, Jaboticabal, São Paulo State, Brazil).

For peroxidase activity, leaf disks were homogenized with a mortar and pestle using liquid nitrogen and the powder mixed with $4 \mathrm{ml}$ $0.01 \mathrm{M}$ phosphate buffer $(\mathrm{pH} 6.0)$ at $4^{\circ} \mathrm{C}$. The mixture was centrifuged at $20,000 \mathrm{~g} / 25 \mathrm{~min}$ at $4^{\circ} \mathrm{C}$ and the supernatant was used as enzyme source. Peroxidase activity in leaf tissue was measured by using a direct spectrophometric assay having guaiacol as substrate (10). The results were expressed as absorption units at $470 \mathrm{~nm} / \mathrm{min} / \mathrm{mg}$ protein.

For $\beta-1,3$ glucanase and chitinase activities, leaf disks were homogenized using liquid nitrogen and the powder mixed with $4 \mathrm{ml}$ $100 \mathrm{mM}$ acetate buffer $\left(\mathrm{pH} \mathrm{5.0)}\right.$ at $4^{\circ} \mathrm{C}$. The mixture was centrifuged at 20,000 $\mathrm{g} / 25 \mathrm{~min}$ at $4^{\circ} \mathrm{C}$ and the supernatant was used as enzyme source. $\beta-1,3$ glucanase activity was measured based on the amount of reducing sugars produced after incubation of the sample with laminarin (Sigma Chemical, St. Louis, MO, USA) $(2 ; 1)$. The $\rho$-hydroxybenzoic acid hydrazide was used to determine the amount of released reducing sugars (16). The results were expressed as $\mathrm{mKatal} / \mathrm{mg}$ protein. Chitinase activity was colorimetrically assayed using carboxymethylchitin-remazol brilliant violet (CM-Chitin-RBV $2 \mathrm{mg} / \mathrm{ml}$, Loewe Biochemica GmbH, Otterfing bei Munchen, Germany) as substrate $(30 ; 29)$. The results were expressed as absorption units at $550 \mathrm{~nm} / \mathrm{min} / \mathrm{mg}$ protein.

The amount of proteins in leaf samples was determined by using the Bradford method (5), having bovine serum albumin as standard.

The presence or absence of phytoplasma in the inoculated and non-inoculated plants was demonstrated by using leaf samples collected when symptoms started to appear. Nucleic acid was extracted from fresh leaf tissue and nested-PCR technique was used with four primer pairs : R16mF2-5' AAG ACG AGG ATA ACA GTT GG 3'; R16mR1-5' TTC CCT CTT CTT GCG AAG TTA GGC CAC CGA 3'; R16F2n -5' GAA ACG ACT GCT AAG ACT GG 3'; R16R2-5' TGA CGG GCG GTG TGT ACA AAC CCC G 3' (14).

\section{RESULTS AND DISCUSSION}

Initial symptoms appeared around 40 days after inoculation and the detection of phytoplasma was started by nested PCR. Phytoplasma was always detected in inoculated plants of both hybrids, but it was absent in control plants. The PCR technique did not allow the quantification of phytoplasma concentration in the diseased tissue of resistant or susceptible hybrids.

Peroxidase levels were higher in diseased tissue from inoculated plants when compared to control plants (Figure 1). The presence of phytoplasma caused an average increase in enzyme activity around $89 \%$ in the susceptible hybrid and $54 \%$ in the resistant one. Maximum peroxidase activity for both hybrids was observed at 40-50 days and after that the activity decreased.

The activity of b-1,3 glucanase was higher in infected plants of both hybrids than in non-inoculated plants (Figure 2). For the susceptible hybrid, an average increase of 58\% was observed in the inoculated plants, while for the resistant hybrid the increase was about $28 \%$. Enzyme activity increased during plant growth for both inoculated and non-inoculated plants of the resistant and susceptible hybrids.

Regarding chitinase activity, the results showed that the levels were also higher in inoculated plants of the resistant as well as of the susceptible hybrids when compared to the non-inoculated ones (Figure 3 ). Infected plants of the susceptible hybrid showed an average enzyme activity higher $(13 \%)$ in relation to the resistant hybrid plants $(8 \%)$ During the experiment, chitinase activity decreased up to 40 days, except for the susceptible inoculated plants in which activity increased up to 70 days, decreasing after that.

Peroxidase activity can be related to the resistance level of host plants (13). However, in the present work the enzyme seems to act as an indicator of general host response instead of acting as a defense mechanism, as reported for other host plants (3). There is no evidence that the enzyme could be acting in the resistance of the corn plants to the phytoplasma because the symptoms appeared at the same time in both resistant and susceptible hybrids, and higher levels of enzyme activity were observed in the susceptible one. In apricot and apple plants affected by European stone fruit yellows, caused by a phytoplasma, peroxidase activity was higher in symptomatic plants than in asymptomatic ones $(20 ; 21)$. Higher peroxidase activity was suggested to interfere with $\mathrm{H}_{2} \mathrm{O}_{2}$ concentration and other metabolites allowing higher phytoplasma activity in the tissues. On the other hand, these results are different from those shown for the pathosystem maize-Exserohilum turcicum, in which a rapid increase in peroxidase activity occurred in resistant hybrids resulting in later symptoms (27). In the pathosystem maize-phytoplasma used in the present study only quantitative alterations in peroxidase activity were observed. Determination of peroxidase isoforms could help find out the possible function of each one in relation to the resistance response, 


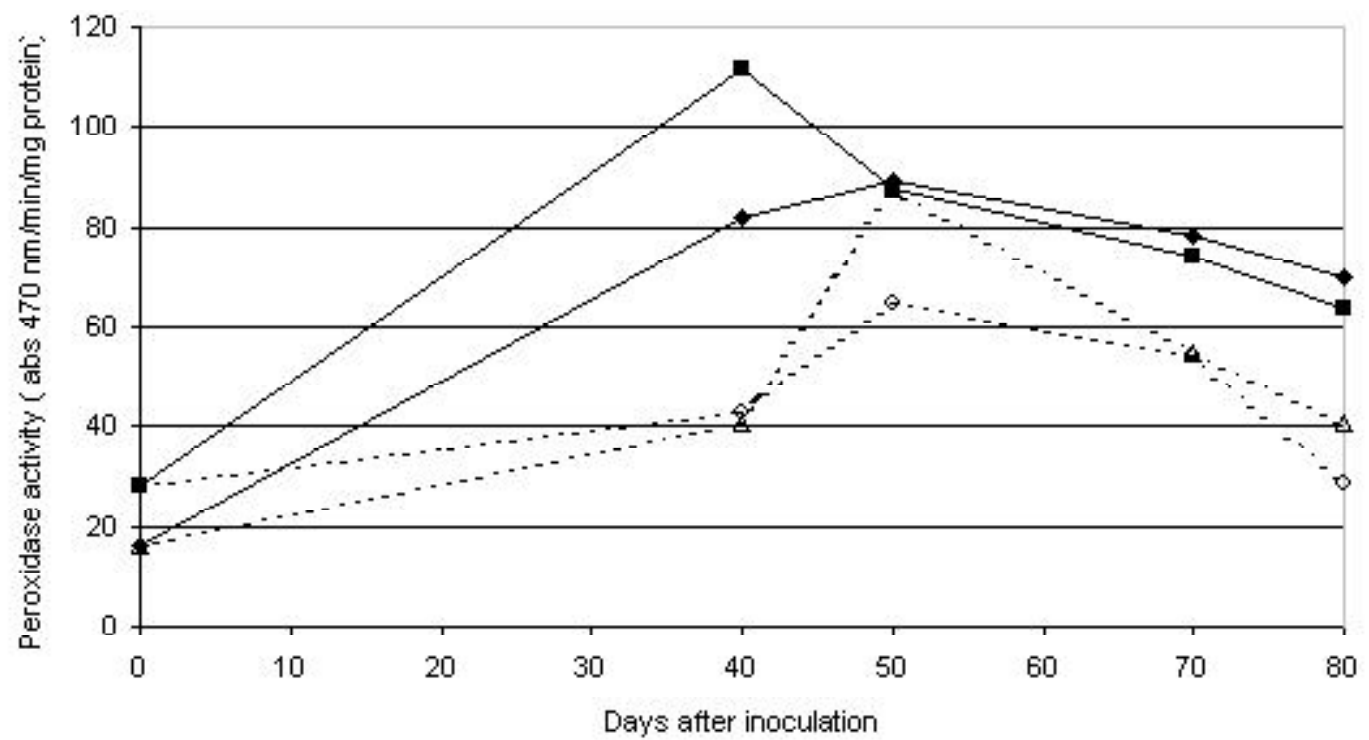

Figure 1. Changes in peroxidase activity in corn leaves of two hybrids (XLX 520 - susceptible; FT9006 - resistant). Ten-day-old plants were inoculated by using infected Dalbulus maydis leafhoppers. Legend: (-o—) XLX520-control; (- - -) XLX520 inoculated; (—- -) FT9006 control; $(\diamond-)$ FT9006 inoculated.

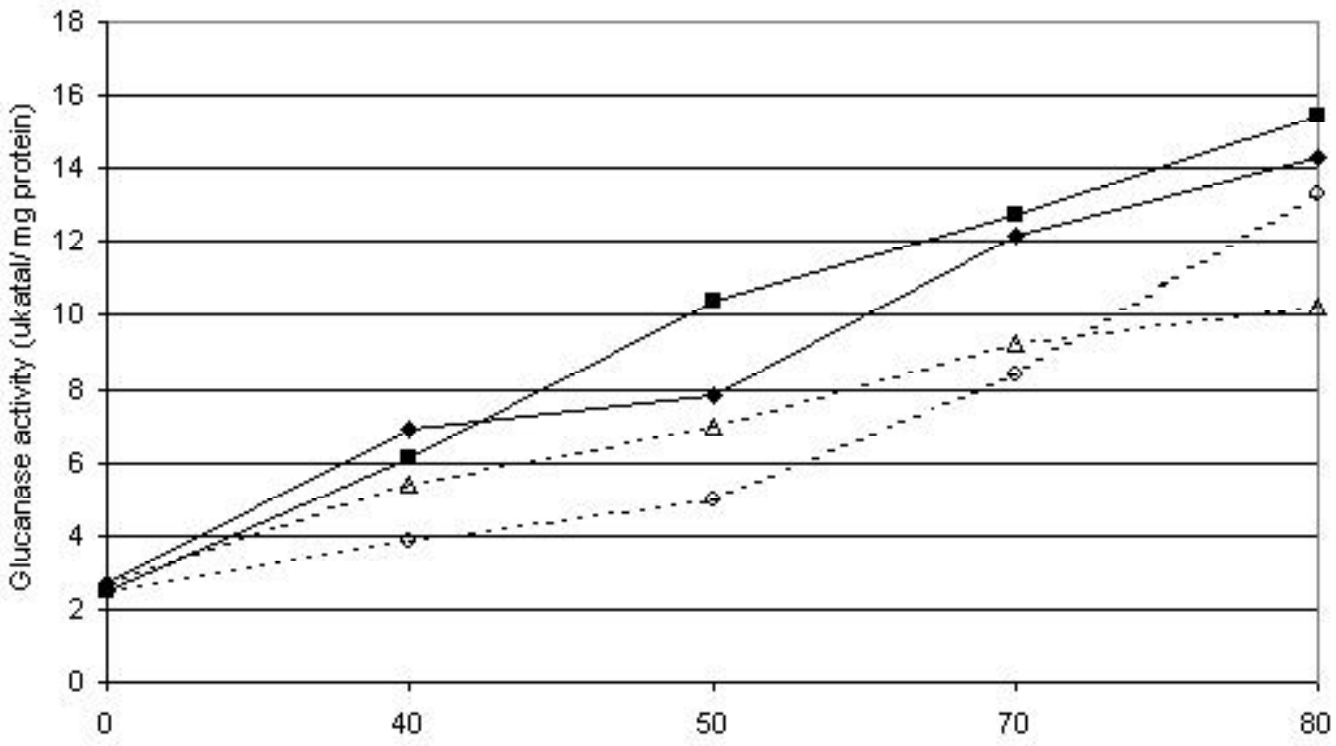

Days after inoculation

Figure 2. Changes in $\beta$-1,3-glucanase activity in corn leaves of two hybrids (XLX 520 - susceptible; FT9006 - resistant). Ten-day-old plants were inoculated by using infected Dalbulus maydis leafhoppers. Legend: (-o-) XLX520-control; (-口-) XLX520 inoculated; (— $\Delta-)$ FT9006 control; (- -) FT9006 inoculated.

as reported for the maize-E. turcicum interaction (28).

In general, a increase in activity was observed for $\beta-1,3$ glucanase and chitinase in plants infected with the maize bushy stunt phytoplasma and higher levels were detected in plants of the susceptible hybrid. In corn plants, infection caused by Brome mosaic virus or treatment with mercury chloride induced the accumulation of B-1,3 glucanase and chitinase in leaf tissue $(22 ; 23)$. The increase in both enzymes is common in plants challenged with biotic and abiotic agents, being related to the resistance responses $(8 ; 17)$. Several basic or acid isoforms have been found for each enzyme, and the role of each specific isoform for both infected and healthy plant tissues is almost unknown. A coordinate induction for a basic isoform of $\beta-1,3$ glucanase and two acid isoforms of chitinase was demonstrated in corn seeds inoculated with Fusarium moniliforme (8). Isoforms of $\beta-1,3$ glucanase and chitinase were found in corn kernels noninoculated or inoculated with Aspergillus flavus, while other different isoforms were present only in infected kernels (11). Some isoforms are constitutive in tissues and have a role in the normal regulatory systems of the plants, and do not exhibit any role on defense mechanisms in host-pathogen interactions (7). For those isoforms, different patterns of activity were observed in various types of tissues (radicles and coleoptiles), indicating that in addition to regulatory functions there is an important specificity related to the tissue where they are produced. 


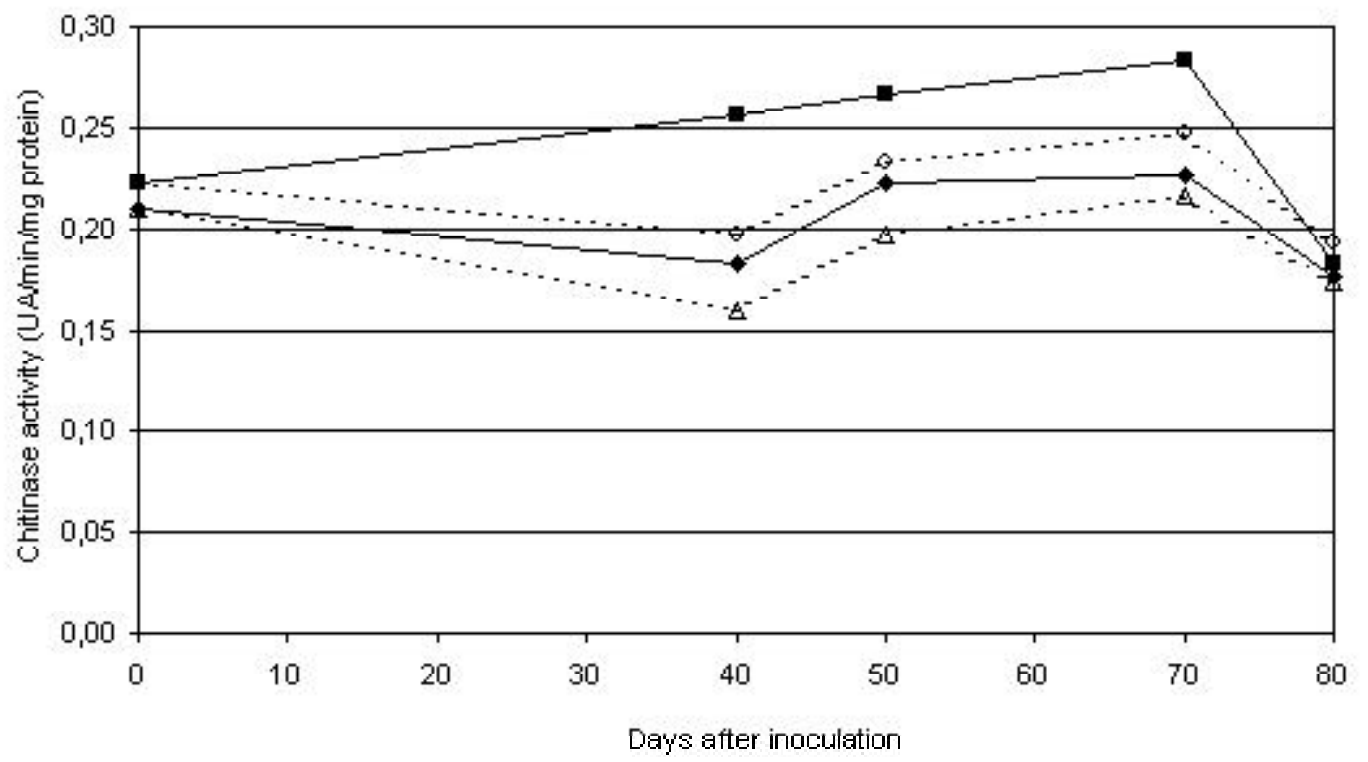

Figure 3. Changes in chitinase activity in corn leaves of two hybrids (XLX 520 - susceptible; FT9006 - resistant). Ten-day-old plants were inoculated by using infected Dalbulus maydis leafhoppers. Legend: (—o-) XLX520-control; (- -) XLX520 inoculated; (— - - ) FT9006 control; (- -) FT9006 inoculated.

The increases in peroxidase, $\beta-1,3$ glucanase and chitinase activity in corn plants inoculated with phytoplasma seem not to have influence on the resistance response of the host. According to Ryals (26), the speed and the intensity of the production of those enzymes could determine resistance or not of plants to pathogens. To understand the role of those enzymes in relation to the defense responses of corn plants inoculated with phytoplasma it would be interesting to know the profile of their respective isoenzymes. Finally, the present study has demonstrated that corn plants infected with the maize bushy phytoplasma exhibited higher activities for peroxidase, $\beta-1,3$ glucanase and chitinase in the susceptible as well as in the resistant hybrids.

\section{ACKNOWLEDGMENTS}

Thanks to Fundação de Amparo a Pesquisa do Estado São Paulo (FAPESP) for financial support this study and Conselho Nacional de Pesquisas $(\mathrm{CNPq})$ for the fellowship awarded. The authors want to thank Dr. Patrícia Cia - ESALQ/USP for artistic assistance.

\section{BIBLIOGRAPHIC REFERENCES}

1.Abelles, F.B.; Foence, L.E. Temporal and hormonal control of $\beta$ 1,3 glucanase in Phaseolus vulgaris. Plant Physiology, Minneapolis, v.45, p. 395-400, 1970.

2.Arnon, D.I. Copper enzymes in isolated chloroplasts in Beta vulgaris. Plant Physiology, Waterbury, v.24, p.1-15, 1949.

3.Asada, K. Ascobate peroxidase: a hydrogen peroxidase-scavenging enzyme in plants. Physiological Plantarum, Copenhagen, v.85, p. 235-241, 1992.

4.Bedendo, I.P.; Davis, R.E.; Dally, E.L. Detection and identification of the maize bushy stunt phytoplasma in corn plants in Brazil using PCR and RFLP. International Journal of Pest Management, London, v.46, p.73-76, 2000.

5.Bradford, M.A. A rapid and sensitive method for the quantitation of microgram quantities of protein utilizing the principle of pro- tein-dye binding. Analytical Biochemistry, New York, v.72, 248-254, 1976.

6.Bravo, J.M.; Campo, S.; Murillo, I.; Coca, M.; San Segundo, B. Fungus-and wound-induced accumulation of mRNA containing a class II chitinase of the pathogenesis-related protein 4 (PR-4) family of maize. Plant Molecular Biology, Dordrecht, 52:745759. 2003.

7.Carpita, N.C. Structure and biogenesis of the cell walls of grasses. Annual Review Plant Pathology, Palo Alto, v.47, p.445-476, 1996.

8.Cordero, M.J.; Raventos D.; San Segundo, B. Differential expression and induction of chitinases and b-1,3-glucanase in response to fungal infection during germination of maize seeds. Molecular Plant-Microbe Interactions, Saint Paul, v.7, p. 23-31, 1994.

9.Christensen, A.B.; Cho, B.H.O.; Naesby, M.; Gregersen, P.L.; Brandt J.; Ordenana, K.; Collinge, D.; Thordal-Christensen, H. The molecular characterization of two barley proteins establishes the novel PR-17 family pathogenesis-related proteins. Molecular Plant Pathology, London, v.3, p. 135-144, p. 2002.

10.Hammerschmidt, T.R.; Nukles, E.M.; Kuc, J. Association of enhanced peroxidase activity with induced systemic resistance of cucumber to Colletotrichum lagenarium. Physiological Plant Pathology, London, v.20, p. 73-82, 1982.

11.Ji, C.; Norton, R.A.; Wicklow, D.T.; Dowd, P.F. Isoform patterns of chitinase and b-1,3- glucanase in mature corn kernels (Zea mays L.) associated with Aspergillus flavus milk stage infection. Journal Agricultural Food Chemistry, Washington, v.48, p. 507-511, 2000.

12.Junqueira, A.C.B.; Bedendo, I.P.; Pascholati, S.F. Biochemical changes in corn plants infected by the maize bushy stunt phytoplasma. Physiological and Molecular Plant Pathology, London, v.65, p. 181-185, 2004.

13.Leherer, R.E. Antifungal effects of peroxidase systems. Journal of Bacteriology, Washington, v.99, p. 361-365, 1969.

14.Lee, I.M.; Gundersen-Rindal, D.E.; Davis, R.E.; Bartoszyk, I.M. Revised classification scheme of phytoplasmas based on RFLP analyses of 16 SrDNA and ribosomal protein gene sequences. International Journal of Systematic Bacteriology, Oxford, v.48, p. 1153-1169, 1998

15.Lepka, M.; Stitt, M.; Moll, E.; Seemuller, E. Effect of phytoplasma infection on concentration and translocation of carbohydra- 
tes and aminoacids in periwinkle and tobacco. Physiological and Molecular Plant Pathology, London, v.55, p. 59-68, 1999.

16.Lever, M.A. A new reaction for colorimetric determination of carbohydrates. Analytical Biochemistry, New York, v.47, p. 273-279, 1972

17.Lozovaya, V.V.; Waranyuwat, A.; Widholm, J.M. b-1,3- glucanase and resistance to Aspergillus flavus infection in maize. Crop Science, Madison, v.38, p. 1255-1260, 1998.

18. Massola, N.S.; Bedendo, I.P.; Amorim, L.; Lopes, J.R.S. Quantificação de danos causados pelo enfezamento vermelho e enfezamento pálido do milho em condições de campo. Fitopatologia Brasileira, Brasília, v.24, p 136-142, 1999.

19.McCoy R.E.; Caudwell, A.; Chang, C.J.; Chen, T.A.; Chiykoski, L.N.; Cousin, M.T. Plant diseases associated with mycoplasmalike organisms. In: Whitcomb, F., Tully, J.G. The mycoplasmas. New York. Academic Press, 1989. v.5, cap. 11, p. 545-560.

20.Musetti, R.; Sanita Di Toppi, L.; Ermacora, P.; Favali, M.A. Recovery in apple trees infected with the apple proliferation phytoplasma: an ultrastructural and biochemical study. Phytopathology, Saint Paul, v.94, p.203-208, 2003.

21.Musetti, R.; Sanita Di Toppi, L.; Martini, M.; Ferrini, F.; Loschi, A.; Favali, M.A.; Osler, R. Hydrogen peroxide localization and antioxidant status in the recovery of apricot plants from European stone fruit yellows. European Journal Plant Pathology, Amsterdan, v.112, p. 53-61, 2005.

22.Nasser, W.; Tapia, M.; Kauffman, S.; Momtasser-Kouhsari, S.; Burkard, G. Identification and characterization of maize pathogenesis-related proteins. Plant Molecular Biology, Dordrecht, v. 11, p. 529-538, 1988.

23.Nasser, W.; Tapia, M.; Burkard, G. Maize pathogenesis-related proteins: characterization and cellular distribution of $\beta-1,3$ - glucanases and chitinases induced by brome mosaic virus or mercuric chloride treatment. Physiological and Molecular Plant Pathology, London, v.36, p. 1-14, 1990.

24.Oliveira, E.; Magalhães, P.C.; Gomide, R.L.; Vasconcelos, C.A.; Souza, I.R.P.; Oliveira, C.M.; Cruz, I.; Schaffert, R.E. Growth and nutrition of mollicute-infected maize. Plant Disease, Saint Paul, v.86, p. 945-949, 2002.

25.Oliveira, E.; Resende, R.O.; Pecci, M.P.G.; Laguna, I.G.; Herrera, P.; Cruz, I. Incidência de viroses e enfezamentos e estimativa de perdas causadas por molicutes em milho no Paraná. Pesquisa Agropecuária Brasileira, Brasília, v.38, p. 19-25, 2003.

26.Ryals, J.; Neuenschwander, U.; Willits, M.; Molina, A.; Steiner, H.Y.; Hunt, M. Systemic acquired resistance. Plant Cell, Rockville, v.8, p. 1809-1819, 1996.

27.Shimoni, M.; Bar-Zur, A.; Reuveni, R. The association of peroxidase activity and resistance of maize to Exserohilum turcicum. Journal of Phytopathology, Berlin, v.131, p. 315-321, 1991.

28.Shimoni, M., Bar-Zur, A.; Reuveni, R. Relation between peroxidase, $\beta$-1,3-glucanase, the se gene and partial resistance of maize to Exserohilum turcicum. Canadian Journal of Plant Pathology, Ontario, v.18, p. 403-408, 1996.

29.Stangarlin, J.R.; Pascholati, S.F. Atividades de ribulose-1,5-bifosfatocarboxilase-oxigenase (rubisco), clorofilase, b-1,3- glucanase e quitinase e conteúdo de clorofila em cultivares de feijoeiro (Phaseolus vulgaris) infectados com Uromyces appendicuculatus. Summa Phytopathologica, Boyucatu, v.26, p. 34-42, 2000.

30.Whirt, N.A.; Wolf, G.A. Dye-labelled substrates for the assay and detection of chitinase and lysosyme activity. Journal of Microbiological Methods, Amsterdan, v.12, p. 197-205, 1990. 